乳牛に括ける血液成分とその栄養生理的意義

佐藤 博

東北農業試験場，盛岡市 020-01

\title{
Blood Biochemistry in Dairy Cows; Its Nutritional and Physiological Significance
}

\section{Hiroshi SATo}

Tohoku National Agricultural Experiment Station, Morioka-shi, 020-01

Key words : blood biochemistry, dairy cows, blood metabolite, blood profile, metabolic profile

\section{はじめに}

血液に含まれる栄養素 (metabolite，以下広く血液 成分上よぶ）の濃度は家畜の homeostatic な調節のも とにあるが，泌乳サイクルなど各生産ステージでとに調 和を保ちながら，最む優先的な状態へ代謝の流れを総合 的に変えるための homeorhetic な調節も受けている. しかし，高位生産の牛ほどてれら調節機構が破綻しやす く，正常な濃度域加逸脱する成分むみられ血液分析の 意義が生じてくる.

古くから血液成分値が利用されてきたのは家畜の疾病 診断であり，その場合の検查項目は病状によって決めら れる屯のであった。古うひとつには牧場内（牛群）の健 康・栄養状態をモニターするため特定の成分についてル 一チンに分析するような利用法がある。乙れは Metabolic profile あるいは Blood profile testなどと呼ば れて，1970年代から欧米で武みられてきだ,142,144,150, 153 171.175)。本稿では後者に主眼をおくが，郚床診断的な 利用にあ配慮しつつ血波成分の意味について考えてみる。 対象は乳牛に限定し，子牛および肉用牛については除外 した.

\section{I . 血液成分と採血方法}

採血のための家畜の保定・拘束などによって影響を大
きくうける成分むある. 体内での代謝 (flow) の変化 に上むなって血液中の濃度にその影響が出現するまでの 時間は成分によって大きく異なり，その指標として 'transient time'という用語が使われ ${ }^{933}$ ，その例を表 1 亿示した。 transient time の短い成分においては， 保定加ら採血までに要した時間の長短沉よっては人為的

Table 1. 'Transient time' (time for $10 \%$ concentration change following $50 \%$ increase in flux) for blood metabolites and hormone.

\begin{tabular}{lc}
\hline \hline & Transient time (min) \\
\hline Acetate & 1 \\
FFA & 2 \\
Alanine & 3 \\
Ketones & 5 \\
Lactate & 8 \\
Insulin & 8 \\
Glycine & 15 \\
Lysine & 15 \\
Glucose & 20 \\
Urea & 90 \\
Ca & $60-120$ \\
Chol. (ester) & $20 \mathrm{hr}$ \\
Albumin & 5 days \\
\hline
\end{tabular}

from LindsAY, D. B. (1978) 
誤差の生ずる可能性が高い，また後述のように日内変動 の著しい成分もあり，てれを加味して採血方法（時刻・ 回数など)を決めるべきである.

ホルモン濃度も保定，穿刺などに影響されるととがあ り，また分泌腺から間歇的に放出されることもあるので 目的によってはカテーテル法による多回採血などの必要 性む强調されている ${ }^{96,181,189)}$.

\section{III. 血液成分への内的および外的影響}

1. 年齢

乳牛に扔いて，年齢にともなって濃度变化を示す成分 として広く認められるのは総蛋白・グロブリン (Glob) と無機リン $(\mathrm{Pi})$ である、総蛋白濃度の上昇 ${ }^{62,89,106,142 .}$ 144,163,182) は主に Glob 濃度の上昇 ${ }^{78,142,144,1822}$ とよってい る. てれは感染などを耐過して兔疫成分が増加するため である ${ }^{62)}$. しかし，老齢になるとアルブミン（Alb）濃 度がゆっくりと低下しており ${ }^{62)}$ ，総蛋白濃度もずっと上 昇し続けることはない，血球容積比 (PCV) と血色素 （Hb）濃度も年齢が進むにつれて低下するてとがある

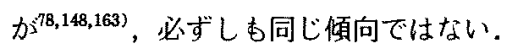

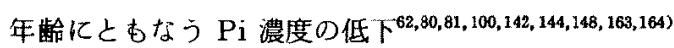
とアルカリ性フォスファターゼ活性 (Al-P)の低下 ${ }^{36,73,}$ 81,100,144，163,166) の現象は，加龄にと多なって骨加らのミネ ラル動員の減退などに関係するすのといえる。短期的に みると $\mathrm{Ca}$ 濃度は年龄が進むにつれて低下するとむい

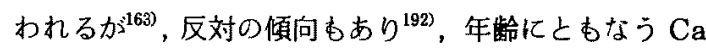
濃度の变化は疑問である。老龄な乳牛では $\mathrm{Mg}$ 濃度が 低いともいわれる(16).

コレステロール (Chol) 濃度は成熟にとあなって上 昇するが4,190,142,144,163)，その上昇も3〜4才までといわれ ている ${ }^{144,183)}$. 初産牛の Chol 濃度は経産牛よりあ高い 例むあるが チニン濃度は年齢にとむなって上昇するといわ㧈る11.

その他の血液成分についても年齢との関係をみた報告 が多いが，必ずしす同一の傾向とはいえず，確定的上は いえない，また，後述のような分婏・泌乳開始による脂 質・糖質・ミネラル関連成分の濃度变化は高龄牛ほど大 きいとされているが（196)，乙れ《関しては年齢（産次） というよりも泌乳量などと関連させて考えるべきである.

2. 品種扔上び遺伝

体液中の蛋白質の免疫特性は遗伝的に支配されている が, 血液中の metabolite やホルモン濃度の品種差は あまり認められていない，欧州系の乳用種間で血液成分 について比較した成績もあるが ${ }^{163)}$ ，一般諭としては木 ルスタイン種など大型種では小型種にくらべて $\mathrm{Hb}$ 濃
度および PCV が低いといわれている

$\mathrm{Chol}^{4,32,58)}$ ，リン脂質の濃度 ${ }^{58)}$ おっよびケトーシス羅患 性 ${ }^{58}$ には遭伝的支配が強いようである. Hb, K 濃度と PCV にも透伝的影響が強いといわ扔るが150)，乙れらは 採血操作の影響をうけやすい成分でもある．採血時の牛 の騒摄などには個体差や系統差の大きいことは多々経験 されることがあり，考虑すべき点といえる.

3. 季節および環境条件

一般に，尿素，Hb 濃度および $\mathrm{PCV}$ は春一夏に高く， 冬期㳊低い47,62,149,150,163,19פ．乙九は飼料加らの蛋白摄取 を反映した6のと考えられ，下記の放牧時の血液性状と あ関係がある.夏期において PCV ゃ Hb 濃度の上昇に 加えて,さらに総蛋白や $\mathrm{Na}$ 濃度の上昇を伴う場合には 飲水が充分に与えられていない可能性が高い ${ }^{95.97 .98)}$. Alb 濃度は夏期に高い上もいわれたが48,123,124)，年次に上っ ては季節差の認められないことああり ${ }^{149)}$,一般には Alb 浀度の季節差は小さいようである.

萩原ら ${ }^{48)}$ による国内での広範な調查によると，夏期 には Chol 濃度が低く, Alb とか Pi 濃度す低下傾向 にあるといわれる。

暑熱環境下では $\mathrm{Hb}$ ，ブドウ糖濃度㧍よび PCVが低 く ${ }^{163)}$ ，Chol とリン脂質および FFA の濃度む低下し ている2 ${ }^{24,163)}$. 蛋白では Alb 濃度が低下して Glob 濃度 が増加する傾向にある ${ }^{143)}$. 尿素濃度す上昇しており蛋 白の異化穴進による ${ }^{5 n}$. 暑熱時に GOT などの活性上昇 をみだ報告あある ${ }^{19)}$.

寒冷時に遊離脂肪酸（FFA）、ブドウ糖濃度括よび PCV が高まるのは ${ }^{43,165)}$ 交感神経系の緊張元進の反映 といえる.放牧開始時期に寒波がくると3ーハイドロキ シ酪酸（3-HB）濃度が上昇することもあるが，気象 の緩和につれて低下している ${ }^{76)}$.

\section{4. 日内变動}

血液成分の日内変動の多くは管理作業（特給飼）に 深く関連する性質のものである.一般には管理作業は日 中（朝と夕含む）に行なわれ，夜間においては牛の活動 性屯低下する。

特に日内変動が注目されてきたのはブドウ糖，FFA， ケトン体および一部のホルモン濃度であった。一般的に は, このような日内变動は栄養要求量の高い牛（および

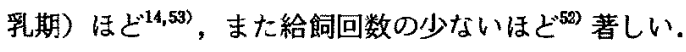

採食前にはFFA とブドウ糖濃度が高く、アセ卜酢

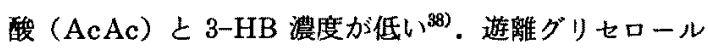
（FG）濃度す飢餓に近い状態で高い ${ }^{125)}$ ．カテーテル法 によって連続的に FFA ${ }^{127,159)}$ やケトン体 ${ }^{127}$ 濃度を調 べてみると（24 時間以上）, てれらの濃度変化は大きく， 
変動係数は $50 \%$ ほどに達する。ケトン体濃度は採食後 に上昇するが ${ }^{102)}$, 特に埰食上の時間的関連が深いのは $3-$ HBである, ${ }^{3,75)}$ 。第一贯壁で吸収されたVFA から3HBがつくられており, 採食後の3-HB 濃度の上昇は 食慨性ケトン血といえる。一方, 採食後の AcAc 濃度 の变化は必ずしも一定の傾向とはいえず，それまで牛が おかれた栄養状態にかかっているとされる65.

血霡の中性脂肪（=トリグリ七ライド； TG）濃度に 6日内変動をみた観察すあるが5 の日内变動は非常に小さい(25).

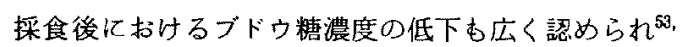
65,66,159), 同時にインスリン濃度の上昇を伴っている ${ }^{53,66)}$. PARKER and LEWIS ${ }^{121}$ によると, 午前 11 時ごるにみ られる最低のブドウ糖濃度しいう現象は旺盛なミルク合 成に関係あるという. すなわち，搾乳の 4 5 時間後に ミルク合成が最も活発であり，その時間带には血液から 乳腺へのブドウ糖の取込みあ最大になるといわれる．血 液の尿素濃度は給飼後数時間以内に最高に達し，液間に は最低になる ${ }^{1599}$ 。乙九は眗料掑取にともなって第一胃 内での $\mathrm{NH}_{3}$ 放出パターンに関係している.

乳牛では血液ミネラル濃度の日内变化はあまり知られ てない，血浆のPi 濃度は採食パターンに関係した变化 を示して採食後に上昇するとが ${ }^{40)}, \mathrm{Pi}$ 濃度のピ一クは 16 時ごろに出見するともいわれている ${ }^{36)}$. Ca 濃度は日 中に低く夜間に高いが，Pi 濃度は反対の傾向を示す ${ }^{159)}$.

乳牛においても一部のホルモン濃度は採食などと関係

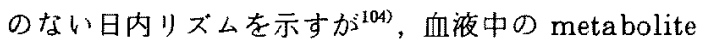
濃度に拈いても採食とは独立した日内リズムが存在する かは未だ不明である。

\section{III . 飼養管理およひ生産性亡血液成分}

\section{1. 飼料の過不足}

（1）飼料不足 - 飢餓：血液中の metabolite 濃度は 給飼レベルによっても影響されるが，粗蛋白 (CP) 給 与を要求量の $75 \%$ ぐいまでげても血液成分の変化 が明らかでないとか ${ }^{180)}$ ，自由採食量の $75 \%$ および50\% に制限した場合では血液成分の反応出現は各 metabolite ごとに違うともいわれている ${ }^{38)}$.

期䋓食)に打いた泌乳4での血液生化学的研究に よるよ ${ }^{6,8)}$ ，絶食によってブドウ糖濃度が低下して，FFA 上ケトン体濃度が上易したが，乳酸および酸酸婊度には ほとんど変化が認められない，また，FFAとケトン体 の濃度变化が同時的に進行するのではなく，FFA を原 料にして ketogenesis が進行するので，循環血液中に おいて守FFA濃度上昇が先行し，1〜2 日遅れてケ
トソ体濃度の上萛がみられる,8

絶食時には総脂質，Chol，リン脂質执よび TG O f n 液中の濃度が上昇し，給飼を再開するとしれら脂軹の濃 度がみな急低下している ${ }^{136)}$. 絶食と再給飼にともなう 血液の脂質濃度の変化は末梢組織（特に乳腺）での利用 量と旰堿からの放出量とのバランスにかかわる現象とい える。また，再給飼後の血采脂質（FFA を除く）は䀣

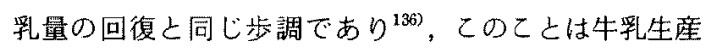
に㧍りる血液脂質成分の重要性を再確認させるすのとい 元当。

(2) Overfeeding 上肝瀻の脂肪浸潤：最近，肥満症 の乳牛か問題になっている。そのような乳牛では剖検によ ると肝䐵に重度な脂肪浸潤があり，代謝病，繁殖障害拉 よび乳房炎にあ関係あるとして注目されている ${ }^{115,141) . ~}$ 高泌乳牛では分姢後に脂肪肝に楩いる頻度が高く，たと え臨床的に正常にみえる乳牛でも泌乳初期には肝茞の脂

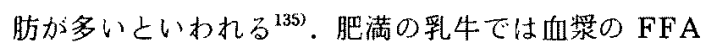
濃度が高く，TG 濃度が低い ${ }^{42)}$ 。乙れは肝缄でのリポ蛋 白の合成および放出の機構に障害があるからであり，肝 障害のマーカー上むいわ扎る狧環血中のオルニチンカル

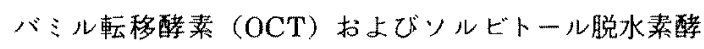
素 (SDH) の活性が異常に高い115)。

脂肪浸潤が重度な牛では高濃度の FFA F $^{46,135)}$ とと屯 に血浆のブドウ糖および Alb 濃度が低い1359，血浆では 総脂質，Chol，リン脂質および TGいずれの濃度よも 低下している．肝蔵では総脂質量は多いが，リン脂質は

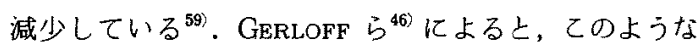
牛では分娭後の体重低下が著しく，発病率拉よび廃用率 が高い上いわれる，血液ではFFA 濃度のほか3-HB

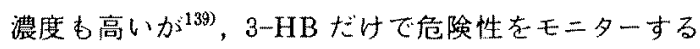
のは難しいといわれる ${ }^{44}$.

2. 給趼法と血液成分

前述のように血液尿素濃度は採食後に上杽するのが一 般といえるが，飼料を 24 時間にわたって連続的に給与 した乳牛では採食後の氺素濃度のビークが消失してい る $^{177)}$. 2 回給飼と 6 回給飼を乳牛で比較してみると， 24 時間採血（カテーテル法）による血丞 FFA 濃度の平 均は多回給飼時に低下しており，インスリン濃度屯低い といわれる年2 .また、ホルマリンで処理した脂肪（防

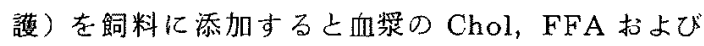

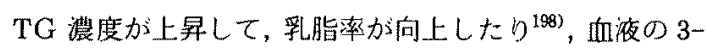

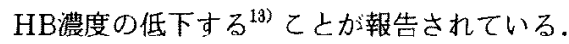

3. 分娩上泌乳開始にともなう変化

分娩と泌乳開始によってブドゥ糖濃度が低下してその 後ゆっくり上上昇するが $3^{5,15,27,64,88,120,131,152)}$, 低下の程度 
と持続期間は牛の泌乳能力および給与飼料によって变つ てくる。一般に分婏後 2 3 週で最低値になるととが多

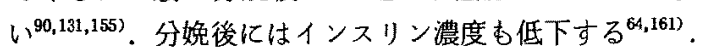
分婏の前後をさらに詳しく検討すると，フドウ糖溄度は 分婏の以前加ら上昇し始如, ${ }^{522}$, 分婏当日には明瞭に上 昇している 後述の FFAの变化之同様に分婏時の交感神経系緊張 の艺進によるものといえる，泌乳開始によってブドウ糖 濃度が低下するが，ブドウ糖の turnover rate は2 3 倍にも高まっている ${ }^{176)}$ 。娃娠末期にはブドウ糖濃度の 低下古観察されている ${ }^{173)}$.

$\mathrm{Hb}$ 濃度と PCV 6分娭および必乳開始によって低下 し, 乳期の進行につれて上昇している3 $34,62,64,152,199)$. ま た泌乳牛の $\mathrm{Hb}$ 濃度と $\mathrm{PCV}$ は非泌乳牛上りも低 い149, 150). Alb 濃度は分婏に上って低下し, 泌乳初期に

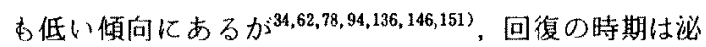
乳水準とか給与飼料によって变ってくる，Glob 濃度は 泌乳初期の約 1 力月くららいは上昇して ${ }^{82,94,152)}$ 泌乳後期 几低下しており ${ }^{78)}$ ，てのような変化は乳房炎などに関係 あるともいわれる ${ }^{94)}$. 総蛋白濃度は妊娠末期に低下する が，主に Glob 浱度の低下のためといえる ${ }^{62,152)}$. 尿菜 濃度は分娭直後に低く，乳期の進行につれて上昇する例

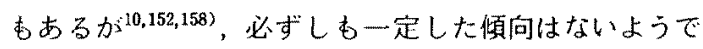
ある.クレアチニン濃度は妊娠後期にゆっくり上昇して 分婏時に急激な上昇を示し，乙の上うな变化は胎児の発 育求よび分娩時における筋組織など蛋白の異化に関係す ると説明されている ${ }^{173)}$.

妊娠末期には総脂質濃度が低く，分娭後にはさらに低 下して最低値を呈する.その後は乳期の進行ととるに徐令 に上显している ${ }^{29.229)}$. Chol（エステル型・遊離型とも）

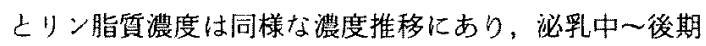
において高い10,31,72,125,136, 150,155, 162). しかし，リン脂質之 Chol 濃度のピークは最高泌乳期よりも遅れており，ま た乳量が低下し始めても高濃度が維持されている ${ }^{18,158)}$ 。 また，Cholとりン脂質の比率は乳期によってほ上んど 変化しない24).

TG 濃度は妊娠未期・乾乳期には高く，分娭・泌乳開

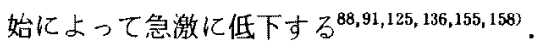

FFA 濃度が分婏時から泌乳初期にかけて最高く， 乳期の進行につれて低下するのは広く知られる ${ }^{27,29,101,}$ 125, 131,136,158,192)。他の成分之はちがって FFA 濃度は妊

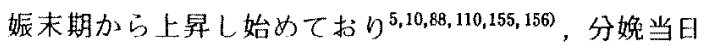
に最む高い5,125,155,156)。乳牛では遊離グリセロールの分 析例は少ないか，FFA 上お招む水同様隹移してい $3^{39,125)}$.
ケトン体濃度も泌乳開始によって上昇するが ${ }^{15,27,29,192)}$,

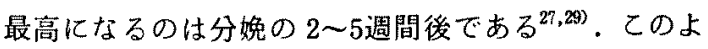
うにケトン体濃度のピークは FFA 濃度のピークより あ遅れており，この事実は牛乳生産能が最高化発揮され， ブドウ糖消費が最高になる時期（すなわち糖新生も最大 に稼働）に ketogenesisがピークになることを意味し ている。ケトーシスにおいてす臨床症状の出現するかな り以前加ら FFA 濃度は著增しているが，ケトン体濃 度が著しく上昇し始めるのはブドウ糖濃度が低下してか らといわれで，ブドウ糖濃度の変化が他の metabolite

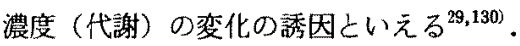

Ca 抢よび Pi 濃度は分娭後に低下している 155, 199). 䎵乳初期飞林いては正常牛においても $\mathrm{Na} \cdot \mathrm{K}$ や Cl なども軽い濃度低下を示している の $\mathrm{Mg}$ 濃度については低下例むあるかが ${ }^{1999}$ ，分婏当日に は上昇例が多い: ${ }^{101,106,155)}$. Mg 濃度は泌乳中の牛で高い

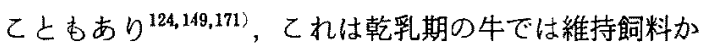
らの Mg 摄取が少ないてとなどによるとも説明されて (る $3^{149)}$.

分婏時抢よび必乳開始期には Glutamic oxaloacetic transaminase (GOT) 活性の上昇むみられる 202)，その上昇は泌乳初期《何らかの疾病を煩った牛は ど著しいとされる ${ }^{1999}$. DALE $5^{299}$ 6分婏・泌乳開始に とむなう变化は認め難いが, 食欲の減退した牛ではGOT 活性㧍よびビリルビン濃度の上昇例をみている. Al-P 活性は分娩後に低下し，泌乳最盛期に加けて上昇傾向を 示している155).

\section{4. 牛乳生産之血液成分}

乳量の多い個体（あるいは時期）ほよ゙ $\mathrm{Hb}$ 濃度と PCV が低い62,78,89, 123,124)。また Alb 濃度が低く，Glob 濃度が高いといわれる ${ }^{146)} . \mathrm{FFA}^{125)} \cdot \mathrm{Mg}^{62,152,192)}$ は乳量 上正の相関関係を示し, $\mathrm{TG}^{18)}$ とブドウ糖62,72,78,152, 192) は負の関係にある。泌乳中の牛では乳酸およびピルビン 酸濃度む低下している”．飼料からのセンイが不足して 乳脂率が低下したような乳牛では血液の酢酸濃度が低下 してインスリンとブドウ糖濃度が上昇するが ${ }^{69,134)}$ ，FFA 濃度には明暸な差が出難い ${ }^{186)}$ 。しかし，そのような場 合には血液の $\mathrm{SDH}$ や乳酸脱水素醉素 $(\mathrm{LDH})$ 活性の 上昇がみられ ${ }^{186,187}$, 代謝面での変化とともに肝細胞へ の傷害があるといえる。

\section{5. 放牧上血液成分}

放牧飼養によっても血液成分に大きな影響がみられ， 特に蛋白とミネラル栄養に関連した成分で著しい，一般 に，放牧中の乳牛では血液の尿素灌度が高い77,120,122, 126, 169 167,184)。放牧中の乳牛では Alb 濃度も高いといわれ 
ているが，蛋白摂取などの要因によって変ってくる222. しかし，放牧初期には総蛋白 ${ }^{160)}$ 上Alb 濃度 ${ }^{77,160,167)}$ が 一時的低下しており，約 1 力月ぐらい経てから総蛋白 濃度が上界に転じるともいわれている ${ }^{167) . ~}$

放牧初期にはブドウ糖 77,160$)$ 之 $\mathrm{FFA}^{184)}$ 濃度の上昇扔 よび Pi 濃度の低下77,160,184)がみられる，放牧開始時に は GOT ट $\mathrm{Mg}$ 濃度の上昇 ${ }^{7 n}$, あるいは $\mathrm{Mg}$ 濃度の低 下とインスリン濃度の上昇もみられる

\section{6. 血液成分之繁殖性}

繁殖成績と血液 metabolite 濃度の関係をみる場合, その原料となる举養素の過不足の両面から検討する必要 がある.

蛋白，エネルギーおよび P の不足に上る繁殖障害は しばしば観察され，血液成分にもそのととが認め得 $3^{68,108,109,114)}$ 。血液中の $\mathrm{Alb}, \mathrm{Ca}$ 抢よび $\mathrm{Pi}$ 濃度の低 い牛群では，受胎率の低下も認められている22)。

Profile test の結果によると繁殖成績の悪い牛群では 血液のブドウ糖濃度の低いことが頻繁に認められて23)， 初回授精で受胎した乳牛のブドウ糖濃度は不受胎区より あ高いてとが示されている ${ }^{16,109}$. MCCLURE ${ }^{108)}$ は粗悪な 粗飼料のみで飼った牛ではブドゥ榶濃度が低く，繁殖成 績む著しく悪いが，粗飼料の飽食または補助飼料給与に よってブドウ糖濃度と上むに受胎率も向上するととを認 めた。ささら彼はインスリン注射法を応用して低血結に した乳牛では性周期が暑延したり，受胎率す低下するこ とを報告している ${ }^{107}$ 。しかし，繁殖成績と血液ブドウ

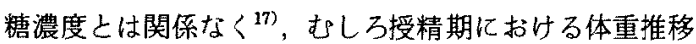
が重要であり，体重が増加傾向にある牛では繁殖成績も よいといわ机ている ${ }^{35,201)}$. 授精（または交配）時にブ ドウ糖やPi 濃度の高い牛では受胎率が高いととも示さ

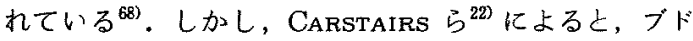
ウ糖枋よび Pi 濃度と繁殖成績との関係は明瞭でないが， これらの濃度が低いとプロゲステロン分泌も弱い傾向に あるといわ机てる.

受胎率の低い牛群では盆血牛の多いこともある 血清のAlb 濃度之繁殖成績も平行関係にあり, 分娩後 のAlb 濃度低下を小さく維持し続け得る牛では繁殖成 績がすぐれている146,148)。また Alb，K 濃度および PCV の高い牛では受胎に要した授精回数が少なく，Glob 濃 度の高い牛では授精回数が多くなるともいわれてい $3^{148)}$.

濃厚飼料多給上センイ飼料不足の飼養条件でむ繁殖性 に問題が多い点については，第一胃内での酷酸発酵の低

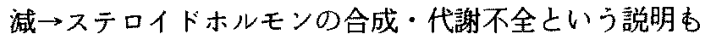
されてきだ5)。センイ飼料の不足は乳脂率などにすぐに
反映されるが，繁殖性への影響が顕著になるには 4〜5 力月かかるとあいわれ，乙れは肝細胞一の傷害の蓄積効 果之考考えられている35).

蛋白とかエネルギーの過剩摄取でも障害が多い，蛋白 の摄取過剩では，肝細胞が傷害され ${ }^{35,178,179)}$, 繁殖性が 害されるとともに血液の尿素濃度や GOT 活性屯上昇 してくる $3^{35)}$. エネルギーの攝取過剩と肝脂肪浸潤につい ては前述した，一般的には P の欠乏による繁殖障害が 重視されている ${ }^{80,82,114)}$. 血清 $\mathrm{Pi}$ 濃度と繁殖成績との間 に負の関係もみられるが，その場合の $\mathrm{Pi}$ 濃度はすへてて

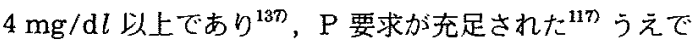
の $\mathrm{P}$ 過給条件亡考元られる. $\mathrm{P}$ 要求が充足されている 乳牛にさらに P を䪔給しても血清のP P 濃度が高まる だけで，繁殖性や生産性の向上はないのが一般的上いえ よう ${ }^{22,116)}$. LARSON ら ${ }^{89)}$ によると血液成分のう繁殖 成績に関係あるのは Se のみとむいわれ，Se 濃度の高 い牛では空胎期間が短縮している. Se は Glutathione peroxidase の構成元素であり, 後産停滞の牛や低受胎 率の牛では血液中のとの醉菜活性が低い之あいわれる が ${ }^{111}$, 後産停滞の有無によってもSe 濃度に差を認め ないとの報告もある ${ }^{20)}$.

性周期之血液成分：生殖ホルモンの分泌は性周期に之 むなって典型的な推移を示すが，他の血液成分について の成績は少ない，Chol 濃度の性周期にともなう变化に は否定的であるが87 , TALAVERA ら ${ }^{174)}$ によるとChol 濃度は黄体期に低下して卵胞期に上昇するといわれる。 ブドウ糖濃度は発情時に上昇し発情後（1３日後）に 低下して招り， $\alpha$-了ミノ態窒素屯発情～発情後期低低 下しているが，尿素踉度には特に周期性を認めないとす る成績もある ${ }^{105)}$ 。同様に De SilvA ${ }^{30)}$ の成績でも発情 時のブドゥ糖濃度は 82 および $69 \mathrm{mg} / \mathrm{d} l$ (末経産牛と 経産牛）といわ机，かなり高濃度と判断できる。乙机は 発情時の興奮などに上ると考えられるが，発情行動とブ ドゥ糖濃度との間には特に関係ないともされている ${ }^{30)}$ 。 血清 GOT 活性にも性周期にともなう推移を認めた報 告もある ${ }^{145)}$.

7. 血液成分の利用之疾病の予測

牧場ごとの血液成分の平均的濃度をすとに飼養管理の 適否を判断し，咱香法の改善に結びつけようとした武み 屯多い。

約 10 年ほど前に SOMMER ${ }^{168)}$ 汃提唱したのは分娩予 定の約 8 週間前に採血して Chol 濃度とGOT 活性を 指標にして, 低 Chol 濃度㧍よび高 GOT 活性の牛では 分婏前に治療する方法であった，上記 2 成分が異常であ っても，治療した牛群では分婏㣪の発病率が著しく減少 
していた188) 。また, PAYNE ら ${ }^{123)}$ の野外調查でも臨床 的卜ラブルの多い牛群では血旅分析の成䋶にも異常が多 くなっている、たとえば，産後麻㾝の多い牛群では $\mathrm{Ca}$ Ł $\mathrm{Mg}$ 浱度の高低が著しかったり，ケトーシスおよ び繁殖障害の多い牧場では血液ブドウ楉濃度が低い とか，産乳性および乳質に問題点の多い牛群では $\mathrm{Alb}$ 濃度が低いなどの特徽がみられている。国内に掠いても， 乳牛の分娩前の血液成分上分婏後の疾病之の関連性につ いての研究が展開されている2,49,50187,88). 血液成分を用 いる Metabolic profileによって牛群の栄盖状態のス クリーニングおよび疾病予測を行なうには限界があると する成績もあるか潘, 50,711，以下引続いて血液成分変動の 栄養生理的意味について考えてみる。

\section{IV. 血液成分の変化とその意味}

泌乳中の乳牛に怙いては飼料給与の適否による影響は 先ず泌乳量に現われ，血液成分への影響はなかなか出現 し難い，たとえば，エネルギ一栄養の变化でもブドウ糖 とケトン体濃度の反応は鈍く，乳量あるいは乳脂肪の脂 肪酸組成が敏感ともいわれる

1. 蛋白栄意と血液成分

乳牛の蛋白栄養はエネルギー䀧取とも深い関係にあり， BLOWEY ら ${ }^{17)}$ は血液のブドウ糖，尿素およびAlbの 3 成分を指標にして蛋白㧍よびエネルギー栄養状態の判定 を唱えている，すなわち，(1)ブドウ糖濃度の低下は工 ネルギー摄取の不足を意味し, (2) Alb 濃度の低下は蛋 白摄取の低下の指標になる。 (3) 尿素濃度の低下は蛋白 摂取の不足あるいはエネルギー掑取の增大を反映すると されている。

1）尿菜濃度：血被の尿素は栄錳状態之腎機能の七二 ターとしての意味があるが,こてでは前者についてのべる. 飼料からの蛋白 (窒素) 摂取之血液尿素濃度上の間には 正の関係があり，給与飼料の CP 水準を高めるにつれ て尿素濃度が上昇している $25,28,84,118)$ 。乙の場合，第一胃 内のアンモニア $\left(\mathrm{NH}_{3}\right)$ 濃度も上昇しているが25), 血䘸 Alb あるいは総蛋白濃度む上昇するとは限らない28,84)。 給与蛋白の質とエネルギー供給によって状況が変ってくる.

第一胃内細菌による $\mathrm{NH}_{3}$ の利用（菌体蛋白の合成） にはエネルギーが不可欠であり，たとえ CP 摄取が多 くてもエネルギー不足では $\mathrm{NH}_{3}$ の利用効率が悪く, 利 用されなかった $\mathrm{NH}_{3}$ は肝䏢で尿素に合成されてしまう

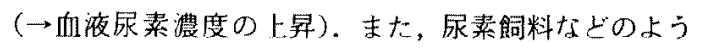
に第一胃内で急速に $\mathrm{NH}_{3}$ を放出する場合にも $\mathrm{N}$ の利 用効率が悪い，たとえ $\mathrm{CP}$ 水準が同じであっても，天 然の蛋白飼料を給与した乳牛では尿素飼料を用いた牛よ
り屯血液尿素浱度が低く ${ }^{67,84,119\rangle}$ ，生産性むすぐれてい $る^{1199}$.また, NPN 飼料と天然飼料の給与の場合で血液 尿素漂度の差が拡大するのは泌乳初期といわれている ${ }^{178)}$. 血清尿素渡度の下限は $7 \mathrm{mg} / \mathrm{d} l$ とされているが ${ }^{117}$ ， エネルギー摄取が多いとこの境界以下になることも多々 みられる

2）総蛋白, Alb 抢よびGlob：Alb 濃度も蛋白栄 養によって变化するが ${ }^{62,79)}$ ，尿素にくらべると反応が荤 くAlb 濃度の低下は長期的な蛋白久乏を意味してい $3^{1522}$. 分婏時にみられる Alb 濃度の低下は肝臓におけ る Alb 合成の低下, Alb 消失の增加および血液内での 㮁釈などよるとされている

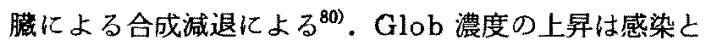
か生産ストレスへの対応と考えられている ${ }^{144)}$. 血采の 膠質浸透圧の維持という面から Alb と Glob は逆の濃 度変化を示すことが多く, 両成分相互の代償によって総 蛋白濃度は比較的一定に保たれている。

3） $\mathrm{PCV}$ と $\mathrm{Hb}$ ：PCV と Hb 濃度蟸白摂取の影 掣をうけ，蛋白不足時には低下しやすいが323)，常に同 様に反応するとは限らず，またその影響の出現には数週 間かかると6いわれている年加．Hb 濃度と PCVは脱水 など細胞外液量の変化によっても影響される ${ }^{95,97,98)}$. ま た前述のように採血ストレスの影響をうけやすい個体も ある.

2. エネルギー摄取と血液成分

(1) ブドウ糖：エネルギー摄取が不足するとブドウ糖 濃度が低下傾向にあるのは周知の事実ではあるが ${ }^{22}$ ， FFA およびヶトン体にくらべるとブドウ糖濃度の調節 機構は強力であり变化も小さい．エネルギー出納の变化 に対してブドゥ糖濃度はあまり敏感でないとが25)，そ のような目的でブドウ桾濃度を指標とするには限界があ るともいわれている33,60,75). しかし，前述の上うにブド ウ糖濃度低下が種々の障害や疾病に関連性を示しており 68,108,109,123)，飼養改善によって泌乳量とか繁殖性が改善 された場合にはブドウ糖濃度の上昇老伴う例あある ${ }^{12 D 。}$ むしろ，エネルギー栄養の判定に扔いては後述の FFA およびケトン体との併用が望まれる ${ }^{23)}$ 。酢酸の transient time は短かいが，採血ストレスの影響を受け難いため 有望な指整であるので ${ }^{93)}$ 分析法の改良がまたれる。

(2) FFA とケトン体：血踏の FFA 濃度は飼料摄取 に敏感に反応し，低栄養時には著しく上昇する し，採血その他のストレス扰よび採食後の時間的要因な どによって濃度変化が拡大される ${ }^{93,121)}$. また分婏の 2 3 週間前加ら FFA 濃度の上昇が始まってお打 ${ }^{155}$ (156)，妊 娠末期や泌乳開始時に㧍いては飼料摄取の過不足之は別 
に obligateな FFA 放出が考えられる ${ }^{33,58,110)}$. エネル ギー栄養に対してはブドウ糖 ${ }^{33,83)}$ 扣よびケトン体濃度 ${ }^{833}$ 上りあ敏感ではあるが，泌乳初期机いて FFA 在指 標とするには限界があるといわれる333. 高泌乳牛之低泌 乳牛の FFA 濃度の差が大きいのは泌乳最盛期のみで あり,ブドウ糖濃度であ同様とされる

FFA はケトン体の前軀物質であり，FFA 濃度が 1.5 $\mathrm{mM}$ まではケトン体濃度は FFA に比例して上昇する が，それ以上ではケトン体濃度が急に上昇してくる ${ }^{122}$ 。 低栄養時に血液のケトン体濃度が上昇するが, $\mathrm{AcAc}$ は肝脿（あるいは乳腺も）での，3-HB は主に第一胃か らの VFAを介しての ketogenesis によっている(日). よって 3-HB 濃度は前述のように採食後時間によって 当変化しており ${ }^{76,93)}$ ，エネルギー出納というよりも飼料 利用の面などで判断価值を持つが，AcAc はエネルギ 一栄養に敏感である ${ }^{93)}$.

ケトン体濃度は採血ストレスの影響も受け難く ${ }^{75)}$ ，血 液ケトン体を指標に用いて牛群の疾病予测および予防の 野外試験它実施されている ${ }^{61,1942}$. 同様にケトーシスの 予察にはブトゥ糖よりす3-HB 濃度が有効な指標にな ると屯いわ机ている60,61). しかし，エネルギー出納がプ ラスの場合にはこれら血液成分とエネルギー出納上の相

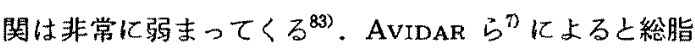
質灙度および総脂質 : ブドウ糖比がエネルギー出納の指 標になるといわれている.

\section{3. 脂質成分}

泌乳牛の血采の $\mathrm{TG}$ は $10 \mathrm{mg} / \mathrm{d} l$ 前後, 多くても 20 $\mathrm{mg} / \mathrm{d} l$ くららいであり，他の動物，たとえばヒトの約 100 $\mathrm{mg} / \mathrm{d} l$, ウサギの約 $60 \mathrm{mg} / \mathrm{d} l$ にくらべて著しく低い.

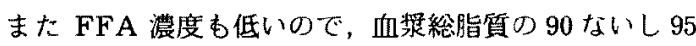
名 前後はChol とリン脂質である ${ }^{113 \text { 132) }}$. TGと FFA はあわせても全脂質の $5 \%$ 程度にすぎないが，循環血液 中および体内での代謝が急速で栄養条件にあ敛敏に反応 している.

Chol，およびリン脂質は血液内では高密度りポ蛋白 として存在し ${ }^{129,132,133)}$ ，乳腺への TG の移行に扔いてキ ヤリアー的な役割を果たしている ${ }^{45,129,133)}$. Chol およ びリン脂質濃度の上昇とエネルギー摄取增加上の関係は 否定的である ${ }^{183)}$. Chol のエステル比は $80 \%$ 前後亡さ れるが ${ }^{155,188)}$ ，やや高い数值 (86-88\%) あ報告されてい $3^{55,56)}$.

Chol 濃度は疾病七の関係でも注目され，分婏前の濃 度か低い乳牛では分婏後の発病が多いといわれる 血液の Chol 濃度が低いのは肝機能の不全にも関係あ $ろ^{35}$. 消化管内寄生虫を駆虫した乳牛ではセンイ消化が
改善されるとともに Chol 膿度が上昇している41)。 また， 繁殖成績の悪い牛群では Chol 濃度が低い上か ${ }^{157}$, 剖 検時に異常を認めた牛と正常牛で生前の Chol 濃度を 比較すると，異常牛で低濃度例が多いことも明らかにさ れてきだ0).

4. ミネラルおよび酵素活性

$\mathrm{P}$ は炭水化物代謝と密接な関係があり,ブドウ糖濃 度が一時的に上昇する時には Pi 淔度低下を伴うことが 多い ${ }^{159)}$. Pi 濃度は P 摂取に比較的反応しやすいが, ベースとなる Pi 濃度には年齢的影響む大きい（前述）。 成牛のPi 濃度は概权4〜 782,200)，あるいは 4 6 $\mathrm{mg}$ / $\mathrm{d} l^{117}$ とされるが，Pi 濃度が異常に低く $(1 \mathrm{mg} / \mathrm{d} l$ 以 下）て屯明瞭な症状の現わ㧈ない例屯ある ${ }^{82)}$. P 久乏で は食欲不振，繁殖障害さらに幼音では発育遅延などをき たしやすい114).

血清 $\mathrm{Ca}$ 濃度の調節は强力であり, 飼料要因に対し ても血清 $\mathrm{Ca}$ 濃度は反応し難く, 飼料の $\mathrm{Ca}$ 水準を把 暒する必要がある。偱環血液中で FFA と Caイオン は結合するが，実験的に FFA 濃度を高めても Ca 1 オンの低下は認められていない境 $\mathrm{Ca}$ 濃度には年 龄による差を認めないが，若い牛ほぼ Caイオンが多 いのは ${ }^{19 n} \mathrm{Al}-\mathrm{P}$ 活性および八イドロキシプロリン濃度 の高い現象 ${ }^{36)}$ などと共に若齢期の活発な骨代謝の反映 といえる。 $\mathrm{Ca}$ 濃度には日間变動す大きく, $\mathrm{Pi}$ 拉よび $\mathrm{Mg}$ と同時に総合的に評価することが力説されてい $3^{14 n}$. Ca 要求量の変化に対范して生体の $\mathrm{Ca}$ 代謝の 調節機構が始動するまでの時間は5〜7日といわれてい $3^{99)}$.

飼料からの $\mathrm{Mg}$ の利用性によって血清 $\mathrm{Mg}$ 濃度む変 ってくる.生有初期の早春の牧草では牛に上る $\mathrm{Mg}$ の 利用性が低く ${ }^{140)}$ ，さらに他のミネラルの影響をうける のは周知のととである。必乳牛の血清 $\mathrm{Mg}$ 濃度が高い のは，泌乳用飼料の高 $\mathrm{Mg}$ 含量で説明されている ${ }^{152)}$.

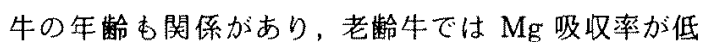
い190). Mg の出納調節においては腎膤が大きく関与し ており尿中 $\mathrm{Mg}$ 排泄には閥值があるので, 尿人の $\mathrm{Mg}$ 排泄によって $\mathrm{Mg}$ 栄養を評価できる ${ }^{190)}$.

血浆の $\mathrm{Na}, \mathrm{K}$ および $\mathrm{Cl}$ 濃度の変化は小さいが, 泌 乳初期のわすかな漂度低下 (前述) は乳汁への大量な分 泌によるといえる。実験的比 $\mathrm{Na}^{74,193)} ， \mathrm{~K}^{128)}$ または $\mathrm{Cl}^{26,37,193)}$ 欠之ををたした乳牛では血液あるいは牛乳中 のそれらミネラルの濃度が低下している。また, 放牧地

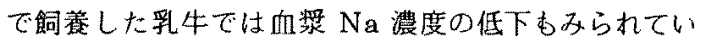
$3^{122)}$.

体内の臓器が傷害されると各蔵器特有の醭素が血液に 
放出されるが，最毛調查例が多いのは肝臟酵菜である。 GOT 活性が高いのむ肝傷害に関係あり，蛋白あるいは エネルギーの過剩掑取などあ原因になっている35,51)。 OCT 活性の上昇屯るられる ${ }^{1799}$. 乳牛における $\gamma$-glutamyl transpeptidase ( $\gamma$-GTP) の組織間分布む特

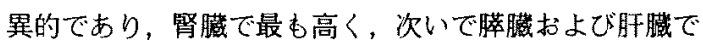
ある ${ }^{138,154)}$ 。しかし，疾病別に血液中の $\gamma$-GTP 活性老 みると肝硬变および肝炎では高いが，腎炎では上昇を認 めず154，また妊期に上る差異も認められないので185)， 旰疾患の指標として利用できるといえる 別に乳牛での $r$-GTP活性をみる上粕類多給の牧場で高 いとの報告むある ${ }^{154)}$. 前述の OCT と SDH 6肝㑺害 の指標として用いられる ${ }^{103)}$ 。弓の他の醉素活性につい ての成績も多いが本稿では省略する。

本稿にで校閲をいただいた其田三夫教授扰よび文献整 理にご尽力された干葉かをり嬢に梁謝の意を表する.

\section{文献}

1) Adams, R.S., W.L. Stout, D.C. Kradel, S.B. Guss, Jr., B.L. Moser and G.A. JunG, J. Dairy Sci., 61 : 1671-1679. 1978.

2）阿久沢正夫・䦗本光司・岩月妙子・森園 充・渡 辺 茂・田代哲之・坂本 紿, 鹿大農報告. 32 : 149-156. 1982.

3) Andersson, L. and K. Lundström, Zbl. Vet. Med. A, $31: 340-349.1984$.

4) Arave, C.W., R.H. Miller and R.C. Lamb, J. Dairy Sci., $58: 423-427.1975$.

5) Athanasiou, V.N. and R.W. Phillips, Am. J. Vet. Res., 39 : 953-956. 1978.

6) Athanasiou, V.N. and R.W. Phillips, Am. J. Vet. Res.,39: 957-960. 1978.

7) Avidar, Y., M. Davidson, B. Israeli and E. Bogin, Zbl. Vet. Med. A, $28: 373-380$. 1981.

8) Baird, G.D., R.J. Heitzman and K.G. HibBit, Biochem. J., 128:1311-1318. 1972.

9) Baird, G.D., M.A. Lomax, H.W. Symonds and S.R. ShaW, Biochem. J., $186: 47-57$. 1980.

10) Belyea, R.L., C.E. Coppock and G.B. LAKE, J. Dairy Sci., $58:$ 1336-1346. 1975.

11) Berglund, B. and R. Oltner, Zbl. Vet. Med. A, 30:59-71. 1983.

12) Bergman, E.N., J. Dairy Sci., 54 : 936-948. 1971.

13) Bines, J.A., P.E. Brumby, J.E. Storry, R.J. Fulford and G.D. Braithwaite, J.
Agric. Sci., 91: 135-150, 1978.

14) Bines, J.A. and I.C. Hart, Occ. Pub. of Br. Soc. Anim. Prod., 1:87-98. 1978.

15) Blom, A.K. and K. Halse, Acta Endocr., 78:306-315. 1975.

16) Blowey, R.W., Occ. Pub. of Br. Soc. Anim. Prod.,1 : 53-57. 1978.

17) Blowey, R.W., D.W. Wood and J.R. Davis, Vet. Rec., 92:691-696. 1973.

18) Blum, J.W., P. Kuntz, H. Leuenberger, K. Gautschi and M. Keller, Anim. Prod., $36: 93-104.1983$.

19) Boots, L.R., T.M. LuDwick and E.R. RADER, J. Dairy Sci., 53 : 1587-1591. 1970.

20) Bostedt, H. and P. Schramel, Z $\mathrm{bl}$. Vet. Med. A. $28: 529-537.1981$.

21) Bowden, D.M., Can. J. Anim. Sci., 51 : 1-13. 1971.

22) Carstairs, J.A., D.A. Morrow and R.S. EMERY, J. Anim. Sci., 51 : 1122-1130. 1980.

23) С.t, S.M., N. Rossow and M. Schafer, Monatsh. Vet-Med., 31 : 41-45. 1976.

24) Christie, W.W., in Lipid Metabolism in Ruminant Animals (Christie. W.W., ed.), 193-225. Pergamon Press, Oxford. 1981.

25) Claypool, D.W., M.C. Pangborn and H.P. Adams, J. Dairy Sci., 63:833-837. 1980.

26) Coppock, C.E., R.A. Aguirre, L.E. Chase, G.B. Lake, E.A. Oltnacu, R.E. McDowell, M.J. Fettman and M.E. Woods, J. Dairy Sci., $62:$ 723-731. 1979.

27) Coulon, J.B., B. Remond, M. Doreau and M. JOURNET, Ann. Rech. Vet., $16: 185-193$. 1985.

28) Cressman, S.G., D.G. Grieve, G.K. MACLEOD, E.E. WhEeler and L.G. Young, J. Dairy Sci., 63:1839-1847. 1980.

29) Dale, H., L. Vic-Mo, and P. Fuellheim, Nord. Ved. Med. 31 : 97-105. 1979.

30) DeSilva, A.W.M.V., G.W. Anderson, F.C. Gwazdauskas, M.L. McGilliard and J.A.Lineweaver, J. Dairy Sci., 64:24092418. 1981.

31) Duncan, W.R.H. and G.A. Garton, Biochem. J., 89 : 414-419. 1963.

32) Edfors-Lilua, I., Bo. Gahne, K. LundSTRÖM, K. DARELIUS and L.E. EDQVIST, Swed. J. Agric. Res., 8 : 113-122. 1978.

33) ERfle, J.D., L.J. Fisher and F.D. SAuer, Can. J. Anim.Sci., 54:293-303. 1974.

34) Esievo, A.K. and W.E. Moore, Res. Vet. Sci., $26: 53-58.1979$.

35) Esslemont, R.J., in Feeding Strategy for 
the High Yielding Dairy Cow (Broster, W.H. and H. SwaN eds.),258-294. Granada Publishing, London. 1979.

36) Evans, J.L., R.E. Fish, Z.B. Lelkes and J.R. Trout, J. Dairy Sci., $59: 1838-1841$. 1976.

37) Fettman, M.J., L.E. Chase, J. BentinckSMith, C.E. Coppock and S.A. ZinN, J. Dairy Sci., 67 : 2321-2335. 1984.

38) Fisher, L.J., P.E. Donnelly, J.B. Hutton and D.M. Duganzich, J. Agric. Sci., 84: 29-37. 1975.

39) Flatlandsmo, K., Acta Vet. Scand., 12 : 489-495. 1971.

40) Forar, F.L., R.L. Kincaid, R.L.Preston and J.K. HIllers, J. Dairy Sci., 65:760763. 1982.

41) Fox, M.T., D.E. Jacobs, R.C. Campling, B.R. Pocknee, R. ClampitT and I.C. Hart, Vet. Rec., 116:257-260. 1985.

42) Fronk, T.J., L.H. Schultz and A.R. Hardie, J. Dairy Sci., 63 : 1080-1090. 1980.

43）藤田 裕・松岡 栄・高橋潤一・鈴木孝俊・藤田 媇, 帯音大研報, 12:323-329. 1982.

44) Gaal, T., C.J. Roberts, I.M. Retd, A.M. DEW and C.M. Copp, Vet. Rec., 113:53-54. 1983.

45) Garton, G.A., J. Lipid Res., 4:237-254. 1963.

46) Gerlofr, B.G., T.H. Herdt and R.S. EMery, J. Am. Vet. Med. Ass., 188: 845850. 1986.

47) Ghergrariu, S., G.J. Rowlands, Al. Pop, N. Danielescu and N.A. Moldovan, Br. Vet. J., 140:600-608. 1984 .

48）萩原茂紀・元井臀子・殷塚二喜, 家衛試研報, 76 : 30-42. 1978.

49）浜名克己・田浦保穂・南正觉耕平 - 秋田真司・萩 尾光美, 鹿大農報告, 36:135-141. 1986.

50）浜名克己 - 田浦保穂 - 南正覚耕平 - 秋田真司 - 萩 尾光美，鹿大農報告，36：143-149．1986。

51) Haraszti, J., O. Szenct, E. Baksai-HorVATH and L. Solti, Acta Vet. Acad. Sci. Hung., $28:$ 197-207. 1980.

52) Hart, I.C., Proc. Nutr. Soc., $42: 181-194$. 1983.

53) Hart, I.C., J.A. Bines, C.C. Balch and A.T. CowIE, Life Sci., 16 : 1285-1291.1975.

54) Hart, I.C., J.A. Bines, S.V. Morant and J.L. RIDLEY, J. Endocr., $77: 333-345.1978$.

55) Hartmann, P.E. and A.K. Lascelles, Aust. J. Biol. Sci., 18 : 114-123. 1965.

56) Hartmann, P.E. and A.K. Lascelles, Aust.
J. Biol. Sci., 18 : 1025-1034. 1965.

57) Hassan, A. and J.D. Roussel, J. Agric. Sci., $85: 409-415.1975$.

58) Henricson, B., G. Jönsson and B. Pehrson, Zbl. Vet. Med. A, 24:89-102. 1977.

59) Herde, T.H., J.S. Liesman, B.J. Gerloff and R.S. EMERY, Am. J. Vet. Res., 44 : 293-296. 1983.

60) Herdt, T.H., J.B. Stevens, J. Linn and V. LARson, Am. J. Vet. Res., 42:1177-1180. 1981.

61) Herdt, T.H., J.B. Srevens, W.G. Olson and V. Larson, Am. J. Vet. Res., 42:503506. 1981.

62) Hewett, C., Acta Vet. Scand., Suppl. 50 : 1-152. 1974

63) Horst, R.L., J.H. Thornton, N.A. JoRGENSEN and L.H. Schultz, J. Dairy Sci., 59: 88-90. 1976.

64) Hove, K., Acta Endocr., 76:513-524. 1974.

65) Hove, K. and A.K. Blom, Acta Endocr., $73: 289-303.1973$.

66) Hove, K. and K. Halse, Acta Vet. Scand., $19: 215-228.1978$.

67) Huber, J.T., J. Anim. Sci., 41:954-961. 1975.

68) Hunter, A.P., N.Z. Vet. J., $25: 305-307$. 1977.

69) Jenny, B.F., C.E. Polan and F.W. Thye, J. Nutr., 104: 379-385. 1974.

70）定免昌臣・中西和典・林 智子・高橋俊幸, 北獣 会誌, $27: 14-17.1983$.

71) Jones, G.M., E.E. Wildman, H.F. Troutt, Jr., T.N. LeSCh, P.E. WAGNER, R.L. BOMAN and N.M. LAnning, J. Dairy Sci., $65: 683-$ 688. 1982.

72) KaPPeL, L.C., R.H. Ingraham, E.B. MoRgan, L. Zeringue, D. Wilson and D.K. BABCOCK, Am. J. Vet. Res., 45: 2607-2612. 1984.

73) Karatzias, H. and H. Scholz, Z bl. Vet. Med. A, 33 : 231-235. 1986.

74）加世田雄時朗, 宮大農報, 29：99-104， 1982.

75) Kauppinen, K., Acta Vet. Scand., $24: 337-$ 348. 1983.

76) KelLy, J.M., Vet. Rec., $101: 499-502.1977$.

77）木村容子 - 元井臀子 - 飯塚三喜, 家衛試研報, 76 : 43-50. 1978.

78) Kitchenham, B.A., G.J. Rowlands and H. Shorbagi, Res. Vet. Sci., 18:249-252. 1975.

79) KRONFeld, D.S., Vet Rec., $77:$ 30-35. 1965.

80) Kronfeld, D.S., J. Am. Vet. Med. Ass., 
161 : 1259-1264. 1972.

81) Kronfeld, D.S., S. Donoghue, R.L. Copp, F.M. Sterns and R.H. ENGLE, J. Dairy Sci., 65: 1925-1933. 1982.

82）小林好作，家畜診療，243:3-7. 1983.

83) Kunz, P.L. and J.W. Blum, Z.f. Tierphysiol. Tierernähng. u. Futtermittelkde., 54 : 239-248. 1985.

84) Kwan, K., C.E. Coppock, G.B. Lake, M.J. Fettman, L.E. Chase and R. E. McDowell, J. Dairy Sci., 60: 1706-1724. 1977.

85) KWEON, O-K., H. ONo, K. OsASA, M. Onda, K. Oboshi, H. Uchisugi, S, KuroSAWA, H. Yamashina and H. Kanagawa, Jpn. J. Vet. Sci., $48:$ 481-486. 1986.

86) Kweon, O-K., H. Ono, T. Seta, M. Onda, K. Oboshi and H. Kanagawa, Jpn. J. Vet. Res., 33:11-17. 1985.

87）権 五鏡・小野 斉・岩住安晃，北獣会誌，28： 251-254. 1984.

88）権 五鏡・小野 斉・山科秀也・金川弘司，北兽 会誌, $29: 54-60.1985$.

89) LARSON, L.L., H.S. MABruCK and S.R. Lowry, J. Dairy Sci., 63:283-289. 1980.

90) Lebeda, M. and J. Prikryloba, Acta Vet. Brno., $50:$ 179-189. 1981.

91) Lebeda, M. and J. Prikryloba, Monatsh. Vet-Med., 37: 737-741. 1982.

92) Lee, A.J., A.R. Twardock, R.H. Bubar, J.E. HALL and C.L. Davis, J. Dairy Sci., 61 : 1652-1670. 1978.

93) Lindsay, D.B., Occ. Pub. of Br. Soc. Anim. Prod., 1 : 99-120. 1978.

94) Little, W., Res. Vet. Sci., $17: 193-199$. 1974.

95) Little, W., K.A. Collis, P.T. Gleed, B.F. Sansom, W.M. Allen and A.J. Quick, Vet. Rec., $106: 547-551.1979$.

96) Little, W., R.D. Harrison and L.A. Williams, Anim. Prod., 41 : 113-117. 1985.

97) Litrte, W., B.F. Sansom, R. Manston and W.M. Allen, Anim. Prod., $27: 79-87$. 1978.

98) Little, W., B.F. Sansom, R. Manston and W.M. Allen, Res. Vet. Sci, $37: 283-289$. 1984.

99) Littledike, E.T., J. Dairy Sci., 59 : 19471953. 1976.

100) Lumsden, J.H., K. Mullen and R. Rowe, Can. J. Comp. Med., 44:24-31. 1980.

101) Luthman, J. and J. Persson, Acta Vet. Scand., $16: 63-75.1975$.

102) Manston, R., G.J. Rowlands, W. Littrle and K.A. Colsts, J. Agric. Sci., $96: 593-$ 598. 1981.

103) Manston, R. and W.M. Allen, Br. Vet. J. $137: 241-247.1981$.

104) Martin, T.C., N.F. Cunningham and N. SABA, J. Endocr., 98: 189-196. 1983.

105) Mason, B.D., C.R. KrishnamuRti and W.D. KITTS, J. Dairy Sci., $56: 744-747$. 1973.

106) McAdam, P.A. and G.O. O'Dell, J. Dairy Sci., 65: 1219-1226. 1982.

107) McClure, T.J., Br. Vet. J., $124: 126-130$. 1968.

108) McClure, T.J., Res. Vet. Sci., 11:247-254. 1970.

109) McClure, T.J. and J.M. Payne, Aust. Vet. J., 54:7-9. 1978.

110) Metz, S.H.M. and S.G. VAN DEN Bergh, Neth. J. Agric.Sci., 25 : 198-211. 1977.

111) Mihailovic, M., Acta Veterinaria (Beograd), $32: 109-114.1982$.

112) Miller, J.K., F.C. Madsen, D.E. Lentz, W.O. Wong, N. RAMSEY, C.E. Tysinger and S.L. HANSARD, J.Dairy Sci., $63: 1073-$ 1079. 1980.

113) Moore, J.H. and W.W. Christie, in Lipid Metabolism in Ruminant Animals (ChrisTIE, W.W. ed.), 227-277, Pergamon Press, Oxford. 1981.

114) Morrow, D.A., J. Am. Vet. Med. Ass., $154: 761-768.1969$.

115) Morrow, D.A., J. Dairy Sci., 59:16251629. 1976.

116) Noller, C.H., A.G. Castro, W.E. Wheeler, D.L. HrLl and N.J. Moeller, J. Dairy Sci., $60: 1932-1940.1977$.

117) NRC, in Nutrient Requirements of Dairy Cattle, 5th ed., p. 5 and 10, Washington, D.C. 1978.

118) Oldham, J.D., W.H. Broster, D.J. NapPeR and J.W. Siviter, Br. J. Nutr., 42:149162. 1979 .

119) Oldham, J.D., D.J. Napper, T. SMith and R.J. FULFORD Br. J. Nutr., $53: 337-345$. 1985.

120) Parker, N.J. and R.W. Blowey, Vet. Rec., $98: 394-404.1976$.

121) Parker, N.J. and G. Lewis, Occ. Pub. of Br. Soc. Anim. Prod., $1:$ 121-132. 1978.

122) Payne, J.M., S.M. Dew, R. Manston and M. Faulks, Vet. Rec., $87: 150-158.1970$.

123) Payne, J.M., G.J. Rowlands, R. Manston and S.M. Dew, Br. Vet. J., $129: 370-381$. 
1973.

124) Payne, J.M., G.J. Rowlands, R. MAnston, S.M. Dew and W.H. Parker, Br. Vet. J., $130: 34-44,1974$.

125) Pehrson, B., Acta Vet. Scand., $12: 230-242$. 1971.

126) Peterson, R.G. and D.E. Waldern, J. Dairy Sci., $64: 822-831.1981$.

127) Phillips, R.W. and V.N. Athanasiou, Am. J. Vet. Res., 39 : 949-952. 1978.

128) Pradhan, K. and R.W. Hemken, J. Dairy Sci., $51:$ 1377-1381. 1968.

129) Puppione, D.L., J. Dairy Sci., 61 : 651-659. 1978.

130) Radloff, H.D, and L.H. Schultz, J. Dairy Sci., $50: 68-72,1967$.

131) Radloff, H.D., L.H. Schultz and W.G. Hokkstra, J. Dairy Sci., 49 : 179-182. 1966.

132) RafHaEL, B.C., P.S. Dimick and D.L. Puppione, J. Dairy Sci., 56:1025-1032. 1973.

133) RaphaEl, B.C., P.S. Dimick and D.L. PuppIONE, J. Dairy Sci., 56:1411-1414. 1973.

134) Ray, S.R., W.J. CRoom, Jr., A.H. RaKes, A.C. Linnerud and J.H. Britt, J. Dairy Sci., 66:2084-2092. 1983.

135) Reid, I.M., C.J. Roberts and R. Manston, Vet. Rec., 104: 75-76. 1979.

136) ReID, I.M., A.J. STARK and R.N. ISENOR, J. Comp. Path., 87 : 241-251. 1977.

137) ReiBhauer, K., Dtsch. Tierärztl. Wschr., $78: 512-516.1971$.

138) Rico, A.G., J.P. Braun, P. Benard and J.P. Thouvenot, J. Dairy Sci., 60: 12831287. 1977.

139) Roberts, C.J., I.M. Reid, G.J. Rowlands and A. Patterson, Vet. Rec., 108:7-9. 1981.

140) Rook, J.A.F. and C.C. BALCH, J. Agric. Sci., 51 : 199-207. 1958.

141) Rossow, C.N. and R. Stäufanbiel, Monatsh. Vet-Med., $38: 404-409.1983$.

142) Roussel, J.D., T.J. ARAnas and S.H. SEYвT, Am. J. Vet. Res., $43: 1658-1660$. 1982.

143) Roussel, J.D., K.L. KoOnCE and M.A. Pinero, J. Dairy Sci., 55 : 1093-1096. 1972.

144) Roussel, J.D., S.H. Seybt and G. Toups, Am. J. Vet. Res., 43: 1075-1077. 1982.

145) Roussel, J.D. and O.T. STALLCuP, J. Dairy Sci., 50 : 1341-1342. 1967.

146) -Rowlands, G.J., Occ. Pub. of Br. Soc.
Anim. Prod., 1 : 59-70. 1978.

147) Rowlands, G.J., Br. Vet. J., $140: 550-557$. 1984.

148) Rowlands, G.J., W. Little and B.A. KITChenhaM, J. Dairy Res., 44 : 1-7. 1977.

149) Rowlandas, G.J., W. Little, R. Manston and S.M. DEw, J. Agric. Sci., 83: 27-35. 1974.

150) Rowlands, G.J. and R. Manston, Livest. Prod. Sci., 3 : 239-256. 1976.

151) Rowlands, G.J. and R. Manston, Res. Vet. Sci., $34:$ 90-96. 1983.

152) Rowlands, G.J., R. Manston, R.M. Pocock and S.M. Dew, J. Dairy Res., 42 : 349-362. 1975.

153) Rowlands, G.J., and R.M. Pocock, Vet. Rec., 98 : 333-338. 1976.

154）斎藤健光，家畜診療，209：23-28. 1980 .

155）佐藤 博，日畜会報，49:333-338，1978.

156）佐藤 博, 栄養生理研究会報, $23: 97-109.1979$.

157）佐藤 博・花坂昭吾・今村照久，日音東北支部会 報，31:8-9.1981.

158）佐藤 博・花咕昭吾・今村照久，日畜会報，52： 653-658. 1981 .

159）佐藤 博·工藤吉夫·三島哲夫・柏木 甲，日畜 会報，55：741-746．1984。

160）佐藤 博・砂子田 哲・杉若輝夫・佐藤彰芳 . 三 浦由雄。日畜会報，52：874-877. 1981.

161) Schwalm, J.W. and L.H. Schultz, J. Dairy Sci., $59: 255-261.1976$.

162) Schwalm, J.W., R. Waterman, G.E. Shook and L.H. Schultz, J. Dairy Sci., 55:5864. 1972

163) Shaffer, L., J.D. Roussel and K.L. KoOnce, J. Dairy Sci., 64:62-70. 1981.

164) Shiga, A., K. Aвe, S. Намamoto, M. Keino, K. Tsukamoto and O. Fujio, Jpn. J. Vet. Sci., $47: 275-283.1985$.

165）四十万谷吉郎・古郡 浩・宮田保彦，日畜会報， $56: 704-710.1985$.

166）清水悦郎·内藤善久 - 村上大藏，岩手大農報， 11： 37-50. 1972.

167）新林恒一，米村寿男，日畜会報，43：677-683. 1972.

168) Sommer, H. Vet. Med. Rev., 1-2: 42-63. 1975.

169) Stevens, J.B. and W.G. Olson, Am. J. Vet. Res., 45:2448-2450. 1984.

170) Stobes, T.H. and D.J. BretT, Aust. J. Agric. Res., 25 : 657-666. 1974.

171) Stout, W.L., D.C. Kradel, G.A. Jung and C.G. Smiley, Prog. Rep. Pennsylvania St. Univ., $358: 1-12.1976$. 
172) Sutron, J.D., I.C. Hart, W.H. Broster, R.T. ElliotT and E. SCHuller, Br. J. Nutr., $56:$ 181-192. 1986.

173) Tainturier, D., J.P. Braun, A.G. Rico and J.P. Thouvenot, Res. Vet. Sci., 37 : 129-131. 1984.

174) Talavera, F., C.S. Park and G.L. Williams, J. Anim. Sci., $60: 1045-1051.1985$.

175) TAsker, J.B., Cornell Vet., 68:460-479. 1978.

176) ThrLsted, S.H., Z.f. Tierphysiol. Tierernähng. u. Futtermittelkde., 53: 1-9. 1985.

177) Thomas, P.C. and M.E. Kelly. J. Dairy Res., 43:1-7. 1976.

178) Treacher, R.J., Occ. Pub. of Br. Soc. Anim. Prod., 1: 133-142. 1978.

179) Treacher, R.J. and K.A. Collis, Res. Vet. Sci., $22:$ 101-104. 1977.

180) Treacher, R.J., W. Little, K.A. Collis and A.J. Stark, J. Dairy Res., 43:357369. 1976.

181) Trenkle, A., J. Dairy Sci., 61:281-293. 1978.

182) Tumbleson, M.E., M.F. Burks and W.E. Wingfield, Cornell Vet., 63:65-71. 1973.

183) Tumbleson, M.E. and D.P. Hutcheson, Proc. Soc. Exp. Biol. Med., 138:10831085. 1971.

184）上村俊一八田忠雄・高橋雅信 - 扇 勉- 尾上貞 堆, 北獣会誌, 30:105-112. 1986.

185) Unglaub, W., A. Afschar and D. Marx, Dtsch. Tierärztl. Wschr., 80: 131-134. 1973.

186) VAN Beukelen, P., Th. Wensing and H.J. BreukINK, Z.f. Tierphysiol. Tierernahng. u. Futtermittelkde., 48:182-195. 1982.
187) Van Dijk, Th. Wensing, P. Van Beukelen and H.J. Breukink, Am. J. Vet. Res., 44 : 674-676. 1983.

188) VARman, P.N. and L.H. Schultz, J. Dairy Sci., 51 : 1971-1974. 1968.

189) Vasilatos, R. and P.J. WanGsness, Endocrinology, $108: 300-304.1981$.

190) Voisin, A., in Grass Tetany (English translation by HerkiotT, C.T.M.), 73-79 and 129-137. Crosby Lockwood \& Son, London. 1963.

191) Wagner. W.C. and W. Hansel, J. Reprod. Fert., 18: 493-500. 1969.

192) Wiener, G., W.S. Russell and A.C. Field, J. Agric., Sci., 94:369-376. 1980.

193) Whitlock, R.H., M.J. Kessler and J.B. TASker, Cornell Vet., 65:512-526. 1975.

194) Whitaker, D.A., J.M. Kelly and E.J. Sмrth, Br. Vet. J., 139:462-463. 1983.

195) Whitlock, R.H., W. Little and G.J. Rowlands, Res. Vet. Sci., $16: 122-124$. 1974.

196) Wohlt, J.E., J.L. Evans and J.R. Trout, J. Dairy Sci., 67 : 2236-2246. 1984.

197）柳谷源悦・堀口隆男・黒川慶一，家畜診療， 218 : 12-14. 1981.

198) Yang, Y.T., R.I. Bal.Dwin and J. Russell, J. Dairy Sci., 61 : 180-188. 1978.

199）吉田康幸, 北獣会誌, 26：207-216. 1982 .

200）吉浦信幸・安藤 弘・向井巡・小林好作，䧗床 獣医, $2:$ No.9, 39-44. 1984.

201) Youdan, P.G. and J.O. King, Br. Vet. J., $133: 635-641.1977$.

202) 'Zamet, C.N., V.F. Colenbrander, R.E. Erb, B. Chew and C.J. Callahan, Theriogenology, $11: 261-272.1979$. 